\title{
The Influence of learners' creativity by Gamification Teaching System
}

\author{
Pei-Fen $\mathrm{Wu}$ \\ Department of Information Management, National Chunghua University of Education \\ 2, ShiDa Road, Changhua, 50074 Taiwan, R.O.C. \\ Phone 886-4-7232105 \#7517, Fax 886-4-7211295, and E-mail pfwu@cc.ncue.edu.tw
}

\begin{abstract}
Li-Shu Lu
Department and Graduate School of Digital Media Design, National Yunlin University of Science and Technology

123 University Road, Section 3, Douliou, Yunlin, 64002, Taiwan, R.O.C.

Phone 886-5-5342601 \#6513, Fax 886-5-531-2169, and E-mail luls@yuntech.edu.tw
\end{abstract}

\author{
Kuang-Yi Fan \\ Graduate Institute of Animation and Multimedia Design,National University of Tainan \\ 33, Sec. 2, Shu-Lin St. Tainan, 70005, Taiwan, R.O.C. \\ Phone 886-6-2313111 \#671, Fax 886-6-2142794, and E-mail kuangyi@mail.nutn.edu.tw
}

\begin{abstract}
This study designs a Gamification of Teaching Assessment System and attempts to find if the system can stimulate learners' creativity. It practices gamification teaching and treats 47 freshmen of university as subjects. By Creativity Assessment Packet, it evaluates the effect on learners' creativity. According to research findings, creative gamification teaching reinforces overall creativity. It significantly influences fluency, flexibility and precision. It means that learners can enhance thinking competence in short time. They have higher precision and develop association by past knowledge and experience in order to provide more diverse solutions.
\end{abstract}

Key words: creative, creativity gamification teaching system, creativity assessment packet

\section{Introduction}

Traditional instructional model gathered up learners in the classrooms and focused on teachers' knowledge instruction in class. After class, by reports and assignments, it enhances learning. Teacher-student interaction in Flipped Classroom enhances learners' learning motivation [1]. Learners preview video before the class and learn on line according to their learning progress. In class, students and teachers discuss with each other and the core spirit is learners' participation, active learning, cooperation \& discussion and interaction with teachers. Learners become the active ones and teachers transform from original role to lead the learning to guide and assistant of learning. Yeh [2] constructed one online learning game platform "PaGamO" and learners can occupy the territory by solution games after class to expand the power. Classcraft [3] is a free online educational role-playing game that teachers and students play together in the classroom. It accomplishes the goal of learning in the game. Gamification platform develops thinking method and content from learners' perspective and it can enhance learners' active learning.

Thus, based on traditional instructional model, this study introduces creative gamification teaching and develops one creativity gamification teaching system. Progress of curriculum becomes flexible and it supports interaction between teachers and students, provides various types of game and records learners' research process. In the content of this curriculum, by making digital game as an example, through gamification teaching, it instructs game making and triggers learners' learning motivation and enthusiasm by their preference for games in order to explore effect on learners' creativity.

Visualization of system can effectively support concept of Gamification to strengthen learners' self-control and recognition [4]. Thus, characteristics of the creativity gamification teaching system are shown below: (1) flexibility: the system complies with different class activities, including instruction, test, reports and evaluations to manage different types of game. (2) interaction: the system can cope with progress and rules of class activities, such as learners' speeches, interaction between teachers and students, etc. (3) gaming: the system can manage figures of learners' Gamification, such as states and skills of characters, experience, game properties obtained, etc. (4) recording: the system can collect data of instructional process in class for the following analysis. Purposes of this study: (1) to develop one creativity gamification teaching system in order to practice concept of gamification teaching. (2) to find if Gamification teaching can influence learners' creativity of game making.

\section{Gamification of Education and Creative Teaching}

Currently, Gamification is a new field which develops rapidly. Deterding et al. [5] defined Gamification as using game design elements on "non-game" content. Viau [6] stated that when learners have learning motivation, learning effect can be easily enhanced. Gamification can satisfy the following (1) need of autonomy; (2) demonstration of personal competence by challenge; (3) construction of relationship with others and perceived value in games. These are three main factors to stimulate learning motivation. Instructional Gamification simply applies game elements on education. It is based on games and the content and attribute are remained.

Dicheva et al. [7] realized that practice of research on 
education mostly focuses on expansion of current Learning Management System (LMS) or APP of mobile phones. In other words, learners use it in review after class and advanced study and the courses with physical classrooms. However, in classes of physical classroom, it lacks research on Gamification. As to physical classroom, there is Gamification development system, such as Classcraft [3] and ClassRealm [8]. They both are online role-playing games to enhance learners' interest. By the system, it manages classroom rules and learners' learning performance and situation. However, Sant [9] stated that this kind of system only develops games in "classroom" instead of changing "teaching content".

Creative thinking instruction is important teaching method and it can trigger learners' creativity. Creative thinking instruction should be introduced in different subjects and support traditional teaching to create new field in original base [10]. "Creativity teaching" aims to cultivate students' creativity, trigger learners' learning interest and encourage learners to learn to think. Roles of teachers and students become diverse and interesting.

Williams [11] suggested that in instructional situations, cognitive and affective behaviors significantly influence development of creative potential. With the tools to evaluate cognitive and affective behaviors, it will recognize the progress of learners' creativity. Williams proposed scale on potential creativity [12]: Williams' Creativity Assessment Packet (CAP) which includes 12 simple and unfinished pictures. Subjects accomplish the pictures by painting with their intuitive reaction and name the finished pictures. Scoring is classified into fluency, openness, flexibility, originality, precision, and entitling. By these 6 dimensions, it can effectively measure creativity.

\section{Research Method}

The purpose of this study is to explore effect of creativity gamification teaching system on creativity. The subjects were freshmen of university who did not have digital game making experience. In the process, creativity gamification teaching was implemented. Finally, they should produce the finished work of digital game. Before and after the experiment, this study conducted the measurement by CAP in order to explore effect of gamification teaching system on creativity.

\section{A. Research Hypotheses}

As to effect of creativity gamification teaching on creativity: with learning method of creativity gamification teaching, learners who have never experienced the teaching will receive various stimuluses. It will lead to effect on creativity. Thus, hypotheses are shown below: after creativity gamification teaching,

1. it significantly influences learners' "fluency".

2. it significantly influences learners' "openness".

3. it significantly influences learners' "flexibility".

4. it significantly influences learners' "originality".

5. it significantly influences learners' "precision".

6. it significantly influences learners" "entitling".

\section{B. Design of instructional materials}

The objective of this curriculum is to allow beginners to experience game making process by program teaching. The purpose of the course is game making. By Adobe Flash
Professional development environment and ActionScript 3.0 code, subjects produce Flash / AIR games. Regarding the program of games, knowledge instructed is shown as follows:

1. Basic language of program code.

2. Concept and skill of game design.

3. Practice of AIR cross platform development by Android.

Thus, teaching material designed in this study is based on animation and program instruction. It also enhances creativity learning. Teaching content is introduced according to 6 creativity dimensions of CAP. Correlation between content of teaching materials and creativity instruction is shown in TABLE I. TABLE II is content of different courses. TABLE I

RELATIONSHIP BETWEEN CONTENT OF TEACHING MATERIALS AND CREATIVITY TEACHING

\begin{tabular}{ll}
\hline Content of program teaching & Creativity teaching \\
\hline $\begin{array}{l}\text { Logo animation, frame control and } \\
\text { title of game }\end{array}$ & $\begin{array}{l}\text { openness, originality, } \\
\text { precision, entitling }\end{array}$ \\
\hline Game option button & openness, precision \\
\hline Character introduction/rule of game & openness \\
\hline Game construction mechanism & flexibility, originality \\
\hline Collision and feedback & fluency, flexibility \\
\hline $\begin{array}{l}\text { Control of figure increase and loss } \\
\text { and feedback }\end{array}$ & precision, openness \\
\hline Multiple game control & $\begin{array}{l}\text { fluency, openness, } \\
\text { flexibility }\end{array}$ \\
\hline Pause and finish & openness \\
\hline Music of different scenes & precision \\
\hline Cross platform design & openness, flexibility \\
\hline
\end{tabular}

TABLE II

TEACHING CONTENT OF DIFFERENT COURSES

\begin{tabular}{ll}
\hline Course & Teaching content \\
\hline $\begin{array}{l}\text { The first } \\
\text { course }\end{array}$ & $\begin{array}{l}\text { Introduction of course and signing of } \\
\text { agreement, Williams' CAP pretest, variable } \\
\text { announcement, operator, condition } \\
\text { judgment, loop and array }\end{array}$ \\
\hline $\begin{array}{l}\text { The second } \\
\text { course }\end{array}$ & $\begin{array}{l}\text { Function, object orientation, debug, } \\
\text { animation and frame control }\end{array}$ \\
\hline $\begin{array}{l}\text { The third } \\
\text { course }\end{array}$ & $\begin{array}{l}\text { Time event, mouse and video control, } \\
\text { keyboard and text field control }\end{array}$ \\
\hline $\begin{array}{l}\text { The fourth } \\
\text { course }\end{array}$ & \begin{tabular}{l} 
Sound control and announcement of access \\
\hline $\begin{array}{l}\text { The fifth } \\
\text { course }\end{array}$
\end{tabular} \\
\hline
\end{tabular}

\section{Analysis of scale}

According to pretest and posttest of Williams' Creativity Assessment Packet and experts' evaluation, this study explores learners' change in six dimensions of creativity and effect of creativity gamification teaching.

\section{Experimental subjects, practice time and environment}

This study conducted creativity teaching in one university of central Taiwan. The subjects were 47 freshmen in Department of Information Management. 51.1\% were males and $48.9 \%$ were females. They did not have experience of game making. Group division in experiment was according to learners' free will. There were three groups with 4 subjects in each and eight groups with 5 subjects in each, with a total of 11 groups. Random codes were C1-C11. Experiment was practiced in five weeks. One course was implemented every week, including totally 15 hours. Experimental environment 
was computer classroom with broadcast system in school.

\section{Analysis and Discussion}

\section{A. Expert validity analysis}

In order to examine the effect of learners' experience of creativity gamification teaching on creativity, this study invites two experts in related field for the evaluation. Two experts have working years more than 15 years. For the concern of validity consistency of experts' evaluation, this study adopts the analysis by Levene variance homogeneity and one-way ANOVA. It effectively retrieves 47 samples. As to the result, in creativity pretest homogeneity test, Levene statistics is .006, $\mathrm{P}=.941>.05$, in posttest homogeneity test, Levene statistics is $.005, \mathrm{P}=.942>.05$. It means that two experts variance difference is insignificant. It can be regarded as consistency (Table III). As to creativity pretest of One-way ANOVA, F $=.046, \mathrm{p}$-value is $.831>.05$, posttest $\mathrm{F}=.029$ and $\mathrm{p}$-value is $.864>.05$ (TABLE IV). It does not reach significance level. Thus, the scoring is consistent and it shows expert validity.

TABLE III

LEVENE VARIANCE HOMOGENEITY TEST

\begin{tabular}{lcccc}
\hline Creativity & $\begin{array}{l}\text { Levene } \\
\text { test }\end{array}$ & $\begin{array}{l}\text { Freedom } \\
\text { degree of } \\
\text { numerator }\end{array}$ & $\begin{array}{c}\text { Freedom } \\
\text { degree of } \\
\text { denominator }\end{array}$ & Significance \\
\hline pretest & .006 & 1 & 92 & .941 \\
posttest & .005 & 1 & 92 & .942 \\
\hline
\end{tabular}

TABLE IV

ONE WAY ANOVA

\begin{tabular}{lccccc}
\hline Creativity & $\begin{array}{l}\text { Sum } \\
\text { of square }\end{array}$ & $\begin{array}{c}\text { Degree of } \\
\text { freedom }\end{array}$ & $\begin{array}{l}\text { Average sum } \\
\text { of square }\end{array}$ & F & p-value \\
\hline $\begin{array}{l}\text { Within-group } \\
\text { pretest }\end{array}$ & 43.574 & 1 & 43.574 & .046 & .831 \\
$\begin{array}{l}\text { Within-group } \\
\text { posttest }\end{array}$ & 17.021 & 1 & 17.021 & .029 & .864 \\
\hline
\end{tabular}

B. Pretest and posttest analysis of Williams' Creativity Assessment Packet

According to hypotheses, this study conducts "pair sample T test" on scores of pretest and posttest in order to examine significant difference among the variables. Table $\mathrm{V}$ is statistics of groups and Table VI is pair sample T test.

TABLE V

STATISTICS OF PRETEST AND POSTTEST

\begin{tabular}{llllll}
\hline \multirow{2}{*}{ Group } & & Number & $\begin{array}{l}\text { Average } \\
\text { mean }\end{array}$ & $\begin{array}{c}\text { Standard } \\
\text { deviation }\end{array}$ & $\begin{array}{c}\text { Standard } \\
\text { deviation }\end{array}$ \\
\hline \multirow{2}{*}{ Fluency } & pretest & 47 & 5.23 & .937 & .137 \\
& posttest & 47 & 5.83 & .481 & .070 \\
\hline \multirow{2}{*}{ Openness } & pretest & 47 & 13.330 & 3.1884 & .4651 \\
& posttest & 47 & 14.372 & 2.4814 & .3619 \\
\hline \multirow{2}{*}{ Flexibility } & pretest & 47 & 4.298 & .8576 & .1251 \\
& posttest & 47 & 5.298 & .6729 & .0982 \\
\hline \multirow{2}{*}{ Originality } & pretest & 47 & 12.777 & 3.2867 & .4794 \\
& posttest & 47 & 13.117 & 3.3170 & .4838 \\
\hline \multirow{2}{*}{ Precision } & pretest & 47 & 4.170 & 3.2257 & .4705 \\
& posttest & 47 & 6.489 & 3.3984 & .4957 \\
\hline \multirow{2}{*}{ Entitling } & pretest & 47 & 7.745 & 2.9003 & .4231 \\
& posttest & 47 & 8.128 & 2.0522 & .2993 \\
\hline \multirow{2}{*}{ Total score } & pretest & 47 & 118.376 & 21.5657 & 3.1458 \\
\cline { 2 - 6 } & posttest & 47 & 129.479 & 7.5896 & 1.1065 \\
\hline
\end{tabular}

TABLE VI

PAIR SAMPLE T TEST OF PRETEST AND POSTTEST

\begin{tabular}{llllll}
\hline Dimensions & $\begin{array}{l}\text { Pair variance difference } \\
\text { mean }\end{array}$ & \multicolumn{3}{c}{ pair sample T test } \\
& deviation & t value & $\begin{array}{c}\text { Degree of } \\
\text { freedom }\end{array}$ & p value \\
\hline Fluency & -.596 & .851 & -4.799 & 46 & $.000^{* * *}$ \\
Openness & -1.0426 & 3.8502 & -1.856 & 46 & .070 \\
Flexibility & -1.0000 & .9325 & -7.352 & 46 & $.000^{* * *}$ \\
Originality & -.3404 & 4.4953 & -.519 & 46 & .606 \\
Precision & -2.3191 & 4.3004 & -3.697 & 46 & $.001^{* *}$ \\
Entitling & -.3830 & 3.0076 & -.873 & 46 & .387 \\
Total score & -24.3830 & 33.7246 & -4.957 & 46 & $.000^{* * *}$ \\
\hline
\end{tabular}

\section{Outcome analysis of collaborative learning}

In valid questionnaires, $74.5 \%$ learners' overall creativity is enhanced. 10 of 11 groups show higher Collaborative Creativity. TABLE VII is growth rate of Top Three groups (C3, C2, $\&$ C1) with increased total score of creativity.

TABLE VII

TOP THREE GROUPS WITH GROWTH OF COLLABORATIVE CREATIVITY

\begin{tabular}{|c|c|c|c|}
\hline Code of group & C3 & $\mathrm{C} 2$ & $\mathrm{C} 1$ \\
\hline \multirow{3}{*}{ Creativity } & 122.0 & 142.1 & 153.0 \\
\hline & 171.9 & 186.8 & 195.3 \\
\hline & $40.90 \%$ & $31.46 \%$ & $27.61 \%$ \\
\hline
\end{tabular}

\section{Conclusion}

This study develops a "creativity gamification teaching system" with flexibility, interaction, gamification and recording and introduces it to game program instruction. In order to examine the effect of learners' creativity. There are 47 subjects were reached by the gamification teaching system. Through Williams' Creativity Assessment Packet, it evaluates learners' creativity performance.

According to the result, it shows that overall creativity is reinforced. The learners can enhance thinking competence in short time. Fluency, flexibility and precision are considerably strengthened. They have higher precision and develop association by their past knowledge and experience in order to provide more diverse solutions. By using this system show higher effectiveness on creativity for cooperative learning. This creativity gamification teaching system can effectively enhance learners' interest and motivation, provide multiple solutions and upgrade precision of games.

\section{References}

[1] University of Washington, Center for Teaching and Learning : Flipping the Classroom, 2013, retrieved from

http://www.washington.edu/teaching/teaching-resources/engagi ng-students-in-learning/flipping-the-classroom/.

[2] P. C. Yeh, PaGamo, The Next Paradigm for Online Education, T EDxTaipei, 2013, retrieved from https://www.youtube.com/watc $\mathrm{h}$ ? $\mathrm{v}=7 \mathrm{htkDYcZHUg}$

[3] Classcraft, 2014, retrieved from https://game.classcraft.com.

[4] O. Marie, M. Peter, \& C. Jonas, Visualisation and Gamification of e-Learning and Programming Education. 2015, Electronic 
Journal of e-Learning, 13(6), pp. 441-454.

[5] S. Deterding, D. Dixon, R. Khaled, \& L. Nacke, from game design elements to gamefulness: Defining "gamification". In A. Lugmayr, H. Franssila, C. Safran, \& I. Hammouda (Eds.). MindTrek, 2011, pp.9-15.

[6] R. Viau, La motivation: condition au plaisir d'apprendre et d'enseigner en contexte scolaire. 3e congrès des chercheurs en Éducation. Bruxelles 2004.

[7] D. Dicheva, C. Dichev, G. Agre, \& G. Angelova, Gamification in Education: A Systematic Mapping Study. Educational Technology \& Society, 2015, 18(3), pp.75-88.

[8] Classrealm, 2014, retrieved from http://classrealm.com/

[9] C. Sant, Leveling Up: Evaluating Theoretical Underpinnings and Applications of Gamification in the Classroom. Master's thesis, Peabody College, Vanderbilt University, 2014.

[10] S. R. Lin, H. M. Chou, S. H. Yan, S. C. Gao, A Case Study on the Implementation and Influence of Creative Curriculum in Senior High Schools, Chung Cheng Educational Studies, 2012, 11(2), pp. 73-111.

[11] F. E. Williams, Assessing pupil-teacher behaviors related to a cognitive-affective teaching model. Journal of Research and Development in Education, 1971, 14-22.

[12] F. E. Williams, Assessing creativity across Williams' CUBE model, Gifted Child Quarterly, 1979, (23), 748-756. 
Recent Developments on Information and Communication Technology (ICT) Engineering-Meen, Yang \& Zhao ISBN: 978-981-14-2136-5 